\title{
Electrical conductivity of low-temperature sodium-potassium cryolite melts
}

\author{
Emilia Kubiňáková, Ján Híveš, Vladimír Danielik, \\ Andrea Červenková, Michaela Benköová \\ Institute of Inorganic Chemistry, Technology and Materials, \\ Faculty of Chemical and Food Technology STU in Bratislava, \\ Radlinského 9, 81237 Bratislava, Slovak Republic \\ emilia.kubinakova@stuba.sk
}

\begin{abstract}
Electrical conductivity of NaF-KF-AlF ${ }_{3}$ melts with different ratios of sodium fluoride and potassium fluoride was measured using a pyrolytic boron nitride tube-type cell with constant distance of electrodes. Molar cryolite ratios $\mathrm{MR}=(\mathrm{n}(\mathrm{NaF})+\mathrm{n}(\mathrm{KF})) / \mathrm{n}\left(\mathrm{AlF}_{3}\right)$ varied from 1.5 to 1.2 (with a step 0.1$)$ in the temperature range of $(675-900)^{\circ} \mathrm{C}$. $A C$-techniques with a sine wave signal with small amplitude in the high frequency range were applied. Electrolyte resistance was obtained from nonlinear regression analysis according to equivalent circuit. Concentration and temperature dependency of electrical conductivity was described and defined. Experimental data were compared with literary sources and regression equations.
\end{abstract}

Keywords: electrical conductivity; aluminium electrowinning; low-temperature electrolytes

\section{Introduction}

Electrochemical preparation of primary aluminium has been invented over 132 years ago. In this process, alumina $\left(\mathrm{Al}_{2} \mathrm{O}_{3}\right)$ is dissolved in an electrolyte consisting mainly of liquid sodium cryolite $\left(\mathrm{Na}_{3} \mathrm{AlF}_{6}\right)$ at the temperatures of around $(950-960)^{\circ} \mathrm{C}$. The electrolyte is usually modified by additions of aluminium fluoride $\left(\mathrm{AlF}_{3}\right)$, calcium fluoride $\left(\mathrm{CaF}_{2}\right)$, magnesium fluoride $\left(\mathrm{MgF}_{2}\right)$ or other additives (Thonstad et al., 2001). This process has been optimized and innovated for more than a century (Kvande and Drabløs, 2014). Innovations of the aluminium electrolysis process are focused on using inert electrodes (Galasiu et al., 2007) and new types of electrolytes with lower temperature of primary crystallization (Cassayre et al., 2010). The most fundamental benefits are environmental, economic, and energetic aspects. The NaF-KF$\mathrm{AlF}_{3}$ system seems to be one of the best possible lowtemperature electrolytes for aluminium reduction. The main physico-chemical properties of these new low-temperature electrolytes have been studied in lesser extent. Electrical conductivity is a very important physico-chemical parameter of electrolytes (Híveš and Thonstad, 2004). Huang et al. (2008) measured the electrical conductivity of $\left(\mathrm{Na}_{3} \mathrm{AlF}_{6^{-}}\right.$ $\left.40 \% \mathrm{~K}_{3} \mathrm{AlF}_{6}\right)-\mathrm{AlF}_{3}-\mathrm{Al}_{2} \mathrm{O}_{3}$ melts by the continuously varying cell constant (CVCC) technique. Different additions of $\mathrm{AlF}_{3}$ and $\mathrm{Al}_{2} \mathrm{O}_{3}$ to the basic melt $\left(\mathrm{Na}_{3} \mathrm{AlF}_{6}-40 \quad \% \mathrm{~K}_{3} \mathrm{AlF}_{6}\right)$ were studied. However, the composition of measured electrolytes before the melting, types of fractions ( $\mathrm{mol} \%$ or wt \%) and molar ration (MR), are not listed. Dedyukhin et al. (2009) studied KF-NaF-AlF 3 melts with an addition of $\mathrm{LiF}$ and/or $\mathrm{Al}_{2} \mathrm{O}_{3}$ with $\mathrm{MR}=1.3$ (and 1.5 for three-component melts). The systems were measured from their temperature of primary crystallization (TPC) up to $800{ }^{\circ} \mathrm{C}$. Basic three-component melts were measured in capillary cell and multicomponent melts were measured in a cell with two parallel molybdenum electrodes. Apisarov et al. (2010) described the electrical conductivity of the $\mathrm{KF}-\mathrm{NaF}-\mathrm{AlF}_{3}$ system at the same MRs, temperature ranges, measuring technique as in the previously mentioned paper (Dedyukhin et al., 2009). The last publication by this research group (Dedyukhin et al., 2011) studied the influence of $\mathrm{CaF}_{2}$ on the electrical conductivity of a mixture of cryolite-based electrolytes with $\mathrm{MR}=1.3$ and 1.5. A four-component system was measured in a cell with two parallel Mo electrodes. The melts were studied in a broad temperature range $>50{ }^{\circ} \mathrm{C}$, as it was stated. Another paper focused on the electrical conductivity of $\mathrm{KF}-\mathrm{NaF}-\mathrm{AlF}_{3}$ mixtures was published by Yang et al. (2013), where the CVCC technique was applied to measure electrical conductivity of the basic melt with $\mathrm{MR}=1.2$ to 1.5 and with an addition of $\mathrm{Al}_{2} \mathrm{O}_{3}$ in the temperature range from $750{ }^{\circ} \mathrm{C}$ to $820^{\circ} \mathrm{C}$. The latest paper focused on electrical conductivity of the sodium-potassium cryolite system in wide concentration and temperature ranges were studied by Kubiňáková et al. (2018_1). The operating temperature varied from $660{ }^{\circ} \mathrm{C}$ to at least $870{ }^{\circ} \mathrm{C}$ and MR changed from 1.5 to 1.2. The influence of different mutual ratios of KF and NaF on electrical conductivity was determined. The addition of $\mathrm{NaF}$ was constant for all studied MR; the studied concentrations were $(10,20,40$, and 50) $\mathrm{mol} \%$. 
This paper follows our previous work (Kubiňáková et al., 2018_1). Electrical conductivity was measured for four different MRs (1.5-1.2) and for three various ratios of $\mathrm{KF}$ and $\mathrm{NaF}$. Investigated $\mathrm{NaF}: \mathrm{KF}$ ratios (in mol \%) were $25: 75,50: 50$, and $75: 25$ for all selected MRs. Experimental data were compared with data for low-temperature sodium, potassium and (sodium-potassium) mixture cryolite systems available in literature.

\section{Experimental}

\section{Chemicals}

Sodium fluoride (NaF, p.a., Merck) and sodium chloride (NaCl, p.a., CentralChem) were dried for (3-5) hours at (400-500) ${ }^{\circ} \mathrm{C}$ before use. Aluminium fluoride ( $\mathrm{AlF}_{3}$, Sigma Aldrich) was purified by sublimation (20 hours) in a platinum crucible at the temperature of $1250{ }^{\circ} \mathrm{C}$. Potassium fluoride (KF, p.a., Merck) was dried in a vacuum dryer with $\mathrm{P}_{2} \mathrm{O}_{5}$ for four days and then at $200{ }^{\circ} \mathrm{C}$ under vacuum for another three days.

\section{Apparatus and measuring techniques}

The basic apparatus and electrical conductivity measuring process were described in detail in our previous paper (Kubiňáková et al., 2016). The tube-type conductivity cell consisted of a pyrolytic boron nitride tube with electrodes in constant distance. A Solartron Impedance/Gain Phase Analyzer 1260 and a Solartron ECHI 1287 were used to measure cell impedance. $A C$-techniques were used with a sine wave signal and a small amplitude in the high frequency range. The value of the amplitude was about $10 \mathrm{mV}$, frequency was varied from $100 \mathrm{~Hz}$ to $100 \mathrm{kHz}$, and 61 readings were taken within this range. The measured impedance diagrams were evaluated by the nonlinear regression analysis using the method of equivalent circuit. The obtained values of electrolyte resistance were used to evaluate electrical conductivities of the melts using Eq. 1;

$$
\kappa=\frac{l}{S \cdot R_{e l}}=\frac{C}{R_{e l}}
$$

where $\kappa$ is electrical conductivity $\left(\Omega^{-1} \mathrm{~cm}^{-1}\right), l$ and $S$ represents parameters of the cell $(\mathrm{cm}$, respectively $\left.\mathrm{cm}^{2}\right), C$ is the cell constant $\left(\mathrm{cm}^{-1}\right)$, and $R_{e l}$ is the electrolyte resistance $(\Omega)$. The cell constant was determined by calibration using the sodium chloride melt (Janz, 1988).

\section{Liquidus temperature}

Phase diagrams of the binary $\mathrm{NaF}-\mathrm{AlF}_{3}$ (Solheim et

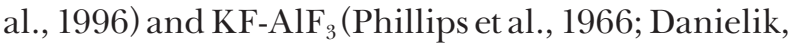
2005) systems are known. Temperature of primary crystallization in the system $\mathrm{Na}_{3} \mathrm{AlF}_{6}-\mathrm{K}_{3} \mathrm{AlF}_{6}$ was first studied by Fellner et al. (1990). A recent study of liquidus temperatures of $\mathrm{KF}-\mathrm{NaF}-\mathrm{AlF}_{3}$ with $\mathrm{CaF}_{2}$ melts with low MR completes the information about TPC of mixture cryolite melts (Apisarov et al., 2011). Multicomponent systems were measured at three MR values and at different mutual ratios of $\mathrm{KF}$ and NaF. The relevance of the temperature of primary crystallization estimation was verified by experimental measurements. It is not possible to measure electrical conductivity even in slightly heterogeneous systems with the method applied.

\section{Results and discussion}

Electrical conductivity of pure sodium cryolite and potassium cryolite systems $\left(\mathrm{NaF}-\mathrm{AlF}_{3}\right.$ and $\mathrm{KF}-\mathrm{AlF}_{3}$, respectively) was measured in the low temperature area (Kubiňáková et al., 2018_2; Kubiňáková et al., 2018_3). Electrical conductivity higher than that of $\mathrm{KF}-\mathrm{AlF}_{3}$ melts is an advantage of the $\mathrm{NaF}-\mathrm{AlF}_{3}$ system. On the other hand, operating temperatures are lower and alumina solubility is higher in $\mathrm{KF}-\mathrm{AlF}_{3}$ melts than in the sodium ones. However, $\mathrm{KF}-\mathrm{AlF}_{3}$ electrolytes in the industrial process will never be pure potassium mixtures. Sodium oxide is always present in alumina as an impurity and regular additions of alumina into the electrolyte cause accumulation of sodium in the system (Dedyukhin et al., 2009). From an industrial point of view, $\mathrm{NaF}-\mathrm{KF}-\mathrm{AlF}_{3}$ systems are more suitable as low temperature electrolytes for aluminium electrolysis. The studied area of ternary NaF-KF-AlF ${ }_{3}$ mixtures in this paper is shown in Fig. 1.

Electrical conductivity of the three-component system NaF-KF-AlF 3 was studied for four different MR values (1.5-1.2) at various temperatures. Three different ratios between $\mathrm{NaF}$ and $\mathrm{KF}$ were studied for all MRs. The investigated mutual ratios (in mol \%) between $\mathrm{NaF}$ and $\mathrm{KF}$ were $25: 75,50: 50$, and $75: 25$. Mole fractions of $\mathrm{NaF}, \mathrm{KF}$ and $\mathrm{AlF}_{3}$ in the ternary systems and the corresponding temperature ranges are given in Tables $1-3$.

Electrical conductivity was sequentially measured for all NaF:KF ratios at the given MRs and tem-

Tab. 1. Concentrations of $\mathrm{NaF}, \mathrm{KF}$, and $\mathrm{AlF}_{3}$ and working temperature range of ternary systems for each MR. Mutual ratio of NaF : KF was $25: 75$.

\begin{tabular}{lcccc}
\hline MR & $\begin{array}{c}\mathbf{x}_{\mathrm{NaF}} \\
(\mathbf{m o l} \%)\end{array}$ & $\begin{array}{c}\mathbf{x}_{\mathrm{KF}} \\
(\mathbf{m o l} \%)\end{array}$ & $\begin{array}{c}\mathbf{x}_{\mathrm{AlF}_{3}} \\
(\mathbf{m o l} \%)\end{array}$ & $\begin{array}{c}\mathbf{t} \\
\left({ }^{\circ} \mathbf{C}\right)\end{array}$ \\
\hline 1.2 & 0.136 & 0.409 & 0.455 & $678-776$ \\
1.3 & 0.141 & 0.424 & 0.435 & $718-824$ \\
1.4 & 0.146 & 0.437 & 0.417 & $766-825$ \\
1.5 & 0.150 & 0.450 & 0.400 & $825-902$ \\
\hline
\end{tabular}


Tab. 2. Concentrations of $\mathrm{NaF}, \mathrm{KF}$, and $\mathrm{AlF}_{3}$ and working temperature range of ternary systems for each MR. Mutual ratio of $\mathrm{NaF}: \mathrm{KF}$ was $50: 50$.

\begin{tabular}{ccccc}
\hline MR & $\begin{array}{c}\mathbf{x}_{\mathrm{NaF}} \\
(\mathbf{m o l} \%)\end{array}$ & $\begin{array}{c}\mathbf{x}_{\mathrm{KF}} \\
(\mathbf{m o l} \%)\end{array}$ & $\begin{array}{c}\mathbf{x}_{\mathrm{AlF}_{3}} \\
(\mathbf{m o l} \%)\end{array}$ & $\begin{array}{c}\mathbf{t} \\
\left({ }^{\circ} \mathbf{C}\right)\end{array}$ \\
\hline 1.2 & 0.273 & 0.273 & 0.454 & $684-786$ \\
1.3 & 0.283 & 0.283 & 0.434 & $723-826$ \\
1.4 & 0.292 & 0.292 & 0.416 & $733-824$ \\
1.5 & 0.300 & 0.300 & 0.400 & $815-879$ \\
\hline
\end{tabular}

Tab. 3. Concentrations of $\mathrm{NaF}, \mathrm{KF}$, and $\mathrm{AlF}_{3}$ and working temperature range of ternary systems for each MR. Mutual ratio of NaF : KF was $75: 25$.

\begin{tabular}{lcccc}
\hline MR & $\begin{array}{c}\mathbf{x}_{\mathrm{NaF}} \\
(\mathbf{m o l} \%)\end{array}$ & $\begin{array}{c}\mathbf{x}_{\mathrm{KF}} \\
(\mathbf{m o l} \%)\end{array}$ & $\begin{array}{c}\mathbf{x}_{\mathrm{AlF}_{3}} \\
(\mathbf{m o l} \%)\end{array}$ & $\begin{array}{c}\mathbf{t} \\
\left({ }^{\circ} \mathbf{C}\right)\end{array}$ \\
\hline 1.2 & 0.409 & 0.136 & 0.455 & $690-792$ \\
1.3 & 0.424 & 0.141 & 0.435 & $715-827$ \\
1.4 & 0.437 & 0.146 & 0.417 & $731-833$ \\
1.5 & 0.450 & 0.150 & 0.400 & $819-901$ \\
\hline
\end{tabular}

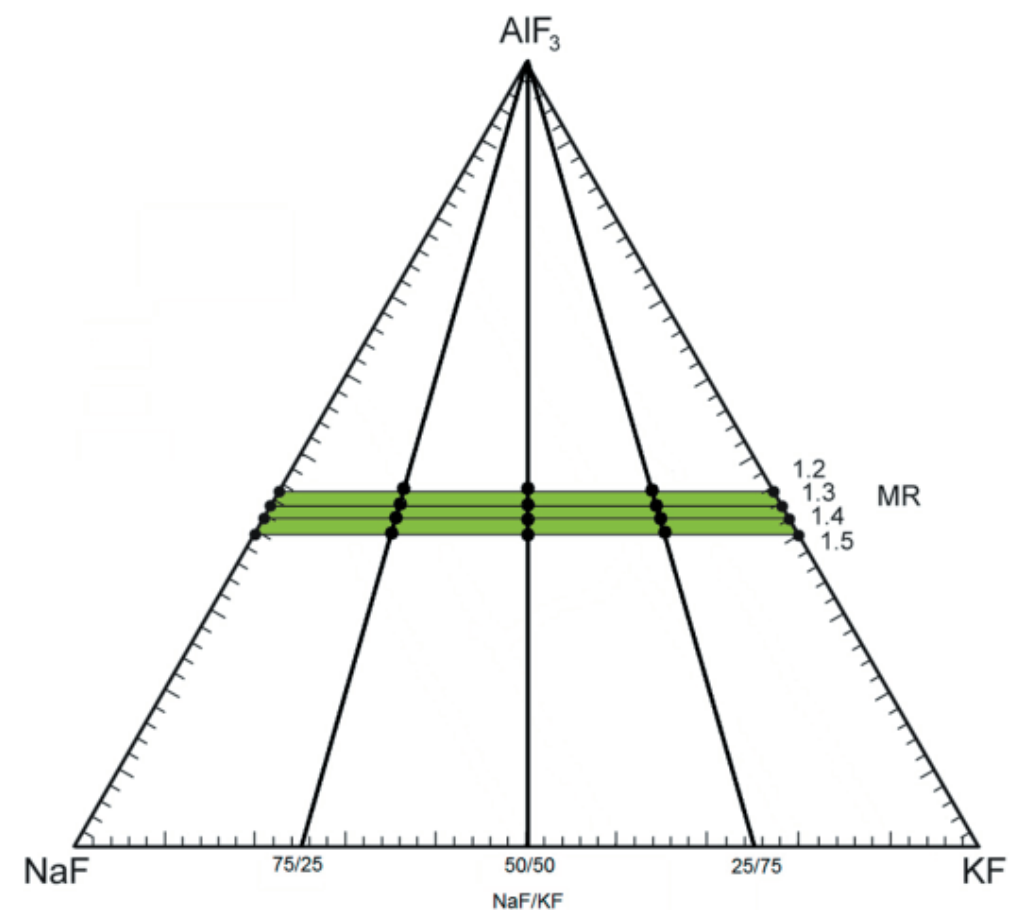

Fig. 1. Measured points of three-component $\mathrm{NaF}-\mathrm{KF}-\mathrm{AlF}_{3}$ mixtures.

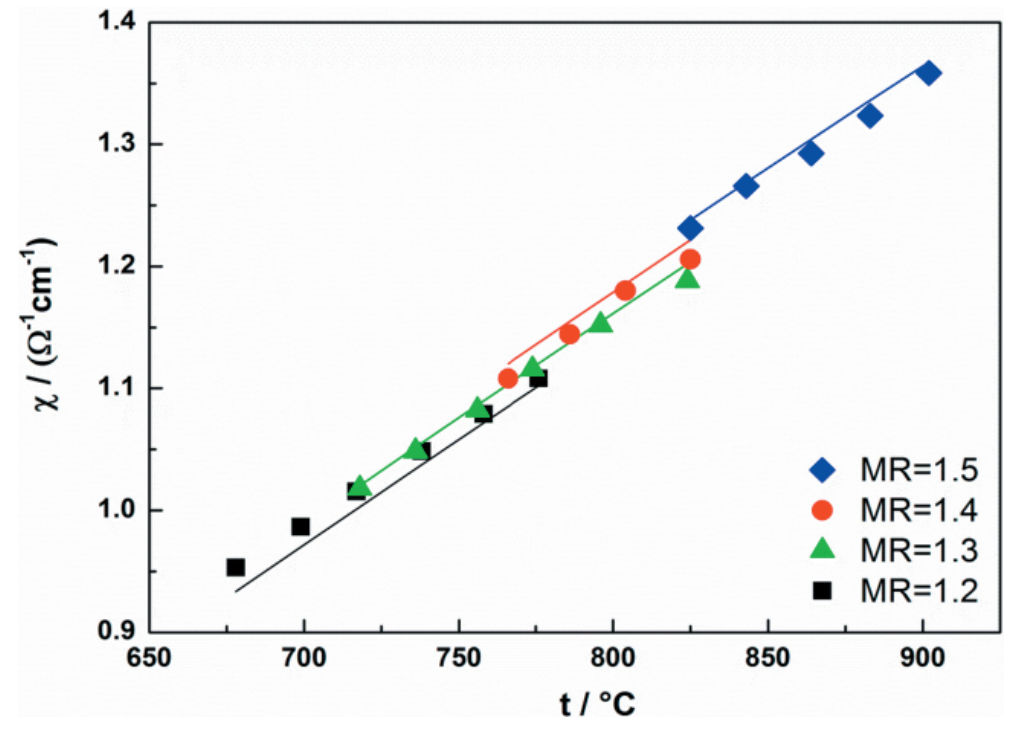

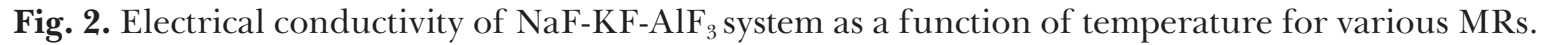
$\mathrm{NaF}: \mathrm{KF}$ ratio was $25: 75$. Points are experimental data, lines are data calculated from Eq. 2. 


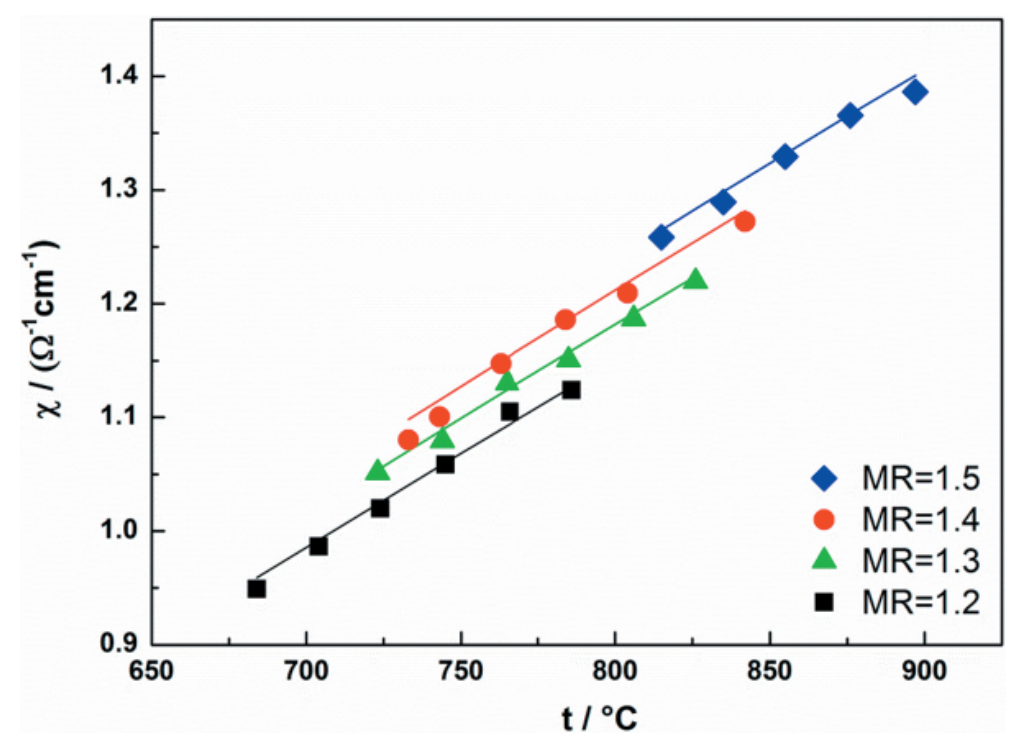

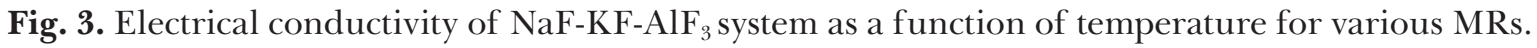
$\mathrm{NaF}$ : KF ratio was $50: 50$. Points are experimental data, lines are data calculated from Eq. 2.

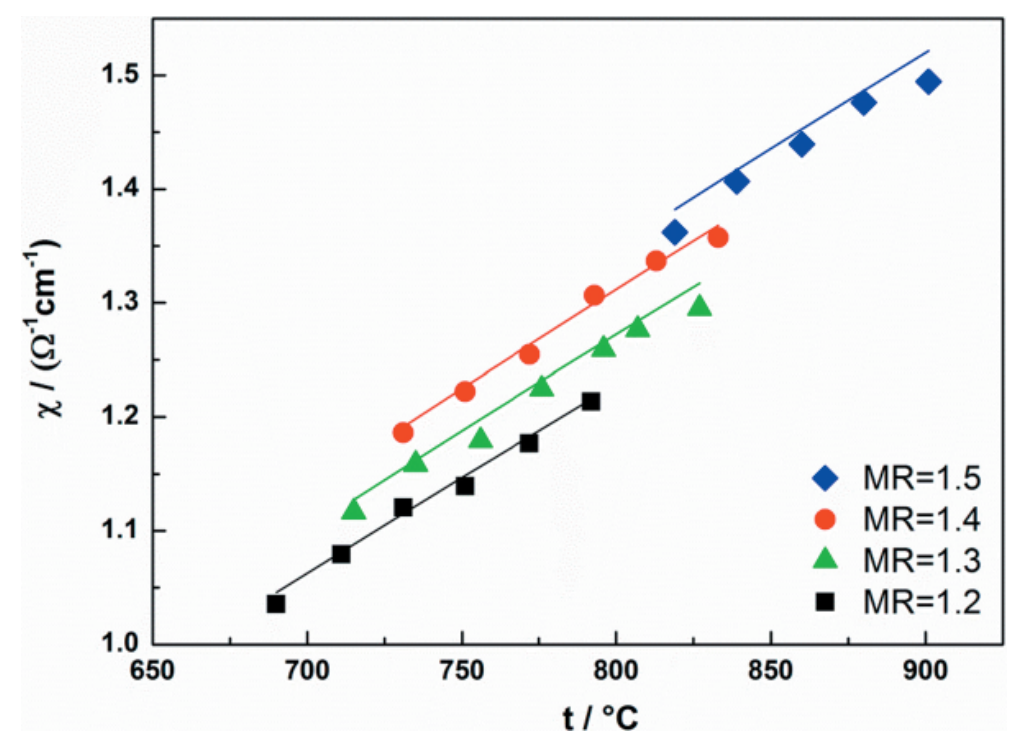

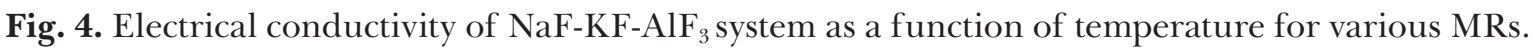
$\mathrm{NaF}: \mathrm{KF}$ ratio was $75: 25$. Points are experimental data, lines are data calculated from Eq. 2.

perature ranges. The values of electrical conductivity decreased with lower MR and decreasing temperature in all measured systems. This trend is the same as in previous investigated binary systems $\mathrm{NaF}_{-} \mathrm{AlF}_{3}$ (Kubiňáková et al., 2018_2) or $\mathrm{KF}_{-} \mathrm{AlF}_{3}$ (Kubiňáková et al., 2018_3). The higher addition of $\mathrm{NaF}$ leads to higher electrical conductivity (Fig. 2-4.). For the $\mathrm{NaF}$ : KF ratios of (25:75) mol \% and (50:50) mol \%, the values of electrical conductivity for all measured MRs were quite similar probably due to the very similar ionic structure of the melt at these additions in the NaF-KF-AlF ${ }_{3}$ system. The decrease of electrical conductivity for the $\mathrm{NaF}$ : KF ratio of (25: 75) mol \% was about $3.67 \%$ in average, compared to the
$\mathrm{NaF}$ : KF ratio of $(50: 50)$ mol \%. Differences between individual MRs were not very significant (Fig. 2. and Fig. 3.). Lower additions of KF to the mixture system $(75 \mathrm{~mol} \%$ of $\mathrm{NaF}$ to $25 \mathrm{~mol} \%$ of $\mathrm{KF}$ ) led to a significant increase of electrical conductivity, which was between the first two NaF : KF ratios of $(25: 75)$ and $(50: 50)$. Differences of the electrical conductivities between the $\mathrm{NaF}: \mathrm{KF}$ ratios of $(50: 50)$ and $(75: 25)$ were about $8.13 \%$ in average (Figs. 3. and 4.). Higher additions of NaF to the mixture system showed a more significant positive impact on the values of electrical conductivities.

The NaF-KF-AlF ${ }_{3}$ system was measured (Kubiňáková et al., 2018_1) for various constant additions of $\mathrm{NaF}$ at different MRs. Mutual ratio of $\mathrm{NaF}$ and KF 
changed with the MRs. The measured experimental data were compared to literary available regression equation for electrical conductivity calculation (Kubiňáková et al., 2018_1):

$$
\begin{gathered}
\kappa /\left(\Omega^{-1} \mathrm{~cm}^{-1}\right)=\left[3.219 x_{N a F}+1.630 x_{K F}+\right. \\
\left.+x_{A l F_{3}}\left(1.805-4.861 x_{N a K}+5.156 x_{N a K}^{2}-2.341 x_{N a K}^{3}\right)\right] \times \\
\times \exp \left[\left(1361 x_{N a F}+1517 x_{K F}+x_{A l F_{3}}\left(2094-587.7 x_{N a K}\right) \cdot\right.\right. \\
\left.\cdot\left(\frac{1}{1300}-\frac{1}{T}\right)\right]
\end{gathered}
$$

where $T$ is temperature in $(\mathrm{K}), x_{i}$ are mole fractions of the components, and term $x_{N a-K}$ represents the mole fraction of $\mathrm{NaF}$ in the binary NaF-KF system $\left(\mathrm{x}_{\mathrm{Na}-\mathrm{K}}=\mathrm{x}_{\mathrm{NaF}} /\left(\mathrm{x}_{\mathrm{KF}}+\mathrm{x}_{\mathrm{NaF}}\right)\right)$. This equation is valid in the concentration range of $\mathrm{x}\left(\mathrm{AlF}_{3}\right)=(40-45.5) \mathrm{mol} \%$, $\mathrm{x}(\mathrm{NaF})=(0-60) \mathrm{mol} \%, \mathrm{x}(\mathrm{KF})=(0-60) \mathrm{mol} \%$ and in the temperature interval from TPC up to $100{ }^{\circ} \mathrm{C}$ overheat. The regression equation (Eq. 2) is an Arrhenius type equation (exponential temperature dependence of electrical conductivity). More detailed description of Eq. 2 derivation was published in a previous paper (Kubiňáková et al., 2018_1).

Equation (Eq. 2) describes all our experimental data very well. The maximum deviation is up to $2.4 \%$ which confirms the validity of the given equation in the defined concentration and temperature ranges.

\section{Conclusion}

Electrical conductivity of NaF-KF-AlF 3 low-temperature cryolite molten systems was investigated. Four different MRs (1.5-1.2) and three various NaF to KF ratios (25:75, $50: 50$, and $75: 25)$ were applied. The $\mathrm{AlF}_{3}$ concentration increasing up to $45.5 \mathrm{~mol} \%$ was found to decrease the working temperature to $(680-690)^{\circ} \mathrm{C}$ for sodium-potassium cryolite melts (if the $\mathrm{NaF}$ concentration varied from $25 \mathrm{~mol} \%$ to $75 \mathrm{~mol} \%)$. Electrical conductivity decreased with the decreasing MR and temperature. An increase in the NaF content led to higher electrical conductivity. The obtained experimental data were compared with the regression equation data available in literature (Kubiňáková et al., 2018_1). Small deviations between experimental and calculated values of electrical conductivity confirm the validity of the regression equation in the defined concentration and temperature ranges.

\section{Acknowledgement}

This publication is the result of the project implementation: Centre for materials, layers and systems for applications and chemical processes under extreme conditions - Stage II, ITMS No.: 26240120021 supported by the Research and Development Operational Program funded by the ERDF. This work was supported also by the Ministry of Education, Science, Research and Sport of the Slovak Republic within the project VEGA 1/0792/17 and by the Slovak Research and Development Agency under the contract no. APVV-17-0183.

\section{References}

Apisarov A, Dedyukhin A, Redkin A, Tkacheva O, Zaikov Y (2010) Russ. J. Electrochem. 46: 633-639.

Apisarov A, Dedyukhin A, Nikolaeva E, Tinghaev P, Tkacheva O, Redkin A, Zaikov Y (2011) Metall. Mater. Trans. B 42: 236-242.

Cassayre L, Palau P, Chamelot P, Massot L (2010) J. Chem. Eng. Data 55: 4549-4560.

Danielik V (2005) Chem. Papers 59: 81-84.

Dedyukhin A, Apisarov A, Tkacheva O, Redkin A, Zaikov Y, Frolov A, Gusev A (2009) ECS Trans 16: 317-324.

Dedyukhin A, Apisarov A, Tinghaev P, Redkin A, Zaikov Y (2011) Light Metals 563-565.

Fellner P, Chrenková M, Gabčová J, Matiašovský K (1990) Chem. Papers 44: 677-684.

Galasiu I, Galasiu R, Thonstad J (2007) Inert Anodes for Aluminium Electrolysis, Düsseldorf.

Híveš J, Thonstad J (2004) Electrochim. Acta 49: 5111-5114.

Huang Y, Lai Y, Tian Z, Li J, Liu Y, Li Q (2008) J. Cent. South. Univ. T. 15: 819-823.

Kubiňáková E, Danielik V, Híveš J (2018_1) J. Electrochem Soc. 165: E793-E797.

Kubiňáková E, Danielik V, Híveš J (2018_2) Electrochim. Acta 265: 474-479.

Kubiňáková E, Danielik V, Híveš J (2018_3) J. Electrochem Soc. 165: E274-E278.

Kubiňáková E, Híveš J, Danielik V (2016) Acta Chimica Slovaca 9: 141-145.

Kvande H, Drabløs PA (2014) J. Occup. Environ. Med 56: 23-32.

Phillips B, Warshaw C, Mockrin I (1966) J. Am. Ceram. Soc. 49: 631-634.

Solheim A, Sterten Å (1996) In: Thonstad J (Ed) Ninth International Symposium on Light Metals Production (pp 225-234). Thondheim.

Thonstad J, Fellner P, Haarberg GM, Híveš J, Kvande H, Sterten $\AA$ (2001) Aluminium Electrolysis, Fundamentals of the Hall-Héroul Process. Düsseldorf.

Yang J, Li W, Yan H, Liu D (2013) Light Metals 689-693. 